\title{
VEGETATION SUCCESSION ASSOCIATED WITH WILDING CONIFER REMOVAL
}

\author{
T.S.H. PAUL ${ }^{1}$ and N.J. LEDGARD ${ }^{2}$ \\ ${ }^{1}$ Scion, Private Bag 3020, Rotorua, New Zealand \\ ${ }^{2}$ Scion, PO Box 29237, Fendalton, Christchurch, New Zealand
}

Corresponding author: thomas.paul@scionresearch.com

\begin{abstract}
Techniques used to remove unwanted wilding conifers can impact on subsequent vegetation successions. Five South Island sites were assessed for vegetation successions after conifers had been removed by four methods, felled to waste, mulched, harvested or killed standing by stem poisoning. Felled conifers created a flush of vigorous plant growth, but this increase was not long-lasting, and the end result was reduced plant biodiversity. Mulching reduced all plant cover initially, but gave poor wilding control. Harvesting led to a dominance of exotics including wildings, whereas solely native plants were found under dead standing trees that had been poisoned. Results indicated that, while there were differences in vegetation composition between the low and high altitude sites, there are good opportunities for manipulating wilding control towards more desirable vegetation covers - particularly involving native plants. Keywords: wildings, conifers, control, succession, natives, exotics.
\end{abstract}

\section{INTRODUCTION}

Wilding conifers are invading depleted grasslands of the eastern South Island hill and high country. Today, they are estimated to affect between 600-800,000 ha of the South Island (North et al. 2007) and control techniques are now widely, and in many cases successfully, practised (Woods 2004; Ledgard \& Woods 2007). The success of such removal operations is often judged solely by whether wilding pines reappear in the cleared areas. However, from a protection and restoration point of view, the removal and possible reoccurrence of an invasive species should not be the only qualitative measure of successful control. The impact of the control operations on the affected ecosystem, particularly the associated vegetation successions, also needs to be considered. The lack of such investigations is surprising, considering that the aim of removal is often to promote a return of the landscape to its former native components and appearance, and the costs of attaining this goal are high.

This paper describes five case studies of wilding control involving four wilding control methods, and reports the outcomes in relation to vegetation status and short term development.

\section{Wilding removal methods and sites}

\section{METHODS}

Four removal methods (felling and leaving on site, mulching, harvesting and stem poisoning) were carried out at one or more sites throughout the South Island of New Zealand (Mt Barker, Craigieburn, Tarndale, Flock Hill and Marlborough Sounds). All sites except the Marlborough Sounds sites were at 900-1000 m above sea level with an annual rainfall of $1100-1200 \mathrm{~mm}$. The Marlborough sites were at $50 \mathrm{~m}$ above sea level with an annual rainfall of $1300 \mathrm{~mm}$. Full details of each method and the sites they were carried out at are described below.

For the first removal method (felling and leaving on site), individual and small stands of wildings (3-8 m tall; 10-25 years old; density ranged from 100 to 2000 stems/ha) 
were felled by chainsaw or scrub-bar at Mt Barker (near Lake Coleridge), Craigieburn Conservation Park (upper Waimakariri river catchment) and Tarndale (on Molesworth station).

In the mulching method, scattered outlier wildings (2-4 $\mathrm{m}$ tall; 8-12 years old; 100 stems/ha) were removed by a tractor-driven drum mulcher at Flock Hill station in the upper Waimakariri river catchment.

For the harvesting method, mature stands of wilding radiata pine $(30-40 \mathrm{~m}$ tall; around 30 years old; 500 stems/ha) were harvested by cable logging in Maraetai Bay, Marlborough Sounds.

The final method, stem poisoning, was examined in Hitaua Bay, Marlborough Sounds, where mature stands of wilding radiata pine (20-30 m tall; 25-35 years old; $500 \mathrm{stems} / \mathrm{ha}$ ) were killed standing by either ring-barking with a chainsaw or stem poisoning with the drill and fill method using a mix of glyphosate and metsulfuron ("Malcom recipe", Ledgard et al. 2008)

\section{Assessments and data analysis}

Relative ground cover and species numbers were assessed in $0.5 \mathrm{~m} \times 0.5 \mathrm{~m}$ plots inside and outside dead trees, felled 6 years previously at Mt Barker (nine paired plots), 4 and 30 years ago at Craigieburn (five paired plots in each plus five plots in the open grassland), and 12-15 years ago at Tarndale (ten paired plots). Analysis was by Welch two sample t-test and Wilcoxon test to compare relative ground cover (visual estimate based on percentage cover estimated to nearest 5\%) and number of species in the plot for the plant groups: grasses, woody plants and herbs, and additional for the grouping into native and introduced species in the various situations (inside and outside decaying trees). Data transformations for plant species numbers per plot (square root transformation) were used to normalise data.

At Flock Hill, vegetation cover was assessed 1 year after mulching along transects $(20 \mathrm{~m}$ long, containing five systematically located $0.5 \mathrm{~m} \times 0.5 \mathrm{~m}$ plots) within the mulched and un-mulched areas (three paired transects). Analysis was by Wilcoxon test to compare relative ground cover of grasses, herbs, shrubs, native and introduced species, as well as wilding and native tree and shrub counts.

In the Marlborough Sounds, vegetation was assessed in $25 \mathrm{~m}^{2}$ plots (three in each stand) 9 years after stem poisoning and 5 years after harvesting. All statistical comparisons were carried out with the statistical software package R (Version 2.6.1).

\section{RESULTS \\ Vegetation succession after felling and leaving on site}

At Mt. Barker, Craigieburn and Tarndale, differences in species numbers and plant cover were evident between areas where trees had been felled compared to areas where there were no wildings (control). Time since felling affected species number and cover of herbs, grasses and woody plants and the cover of native species (Table 1). Within trees felled less than 10 years ago, there was an increase in cover, especially in grass cover (e.g. Craigieburn, grass cover (introduced and native) increased from 50 to 90\%). Many small herbs like Hieracium pilosella and woody species, especially low prostrate species like Coprosma petriei, were suppressed by the increase in grass cover. The increase in cover and the enhanced growth of grasses amongst felled trees was not long-lasting and on sites where the felling was more then 10 years ago both the cover and number of grasses fell back to the same or less than in the control (no wildings). The cover of woody shrubs in sites that had a felling 10 or more years ago was also much smaller than in the control and in the sites with recently felled wildings. The number of native species at sites affected by wildings was much lower compared to the open control plots. However, in the short-term the cover of native species increased relative to control areas, but was significantly lower where wildings were felled over 10 years ago. Introduced species cover was not affected by felling, as there was no difference within felled trees compared to the open grassland control, and there was no difference in the number of introduced species between control plots and areas that had been felled a long time ago. 
TABLE 1: Mean cover (\%) and average number of species per plot $\left(0.25 \mathrm{~m}^{2}\right)$ within areas where trees had been felled and left on site, less than or more than 10 years previously, and in control areas where there were no wildings. Measurements were made at three sites, Mt. Barker, Craigieburn and Tarndale. Values (mean \pm standard error) within each row that have the same letter are not significantly different.

\begin{tabular}{lcccc}
\hline \multirow{2}{*}{$\begin{array}{l}\text { Vegetation } \\
\text { categories }\end{array}$} & \multicolumn{2}{c}{ Within felled trees $^{\text {Cover }(\%)}$} & \multicolumn{1}{c}{$\begin{array}{c}\text { Control (no } \\
\text { wildings })^{4}\end{array}$} & $\begin{array}{c}\text { Significance } \\
\text { level }\end{array}$ \\
\cline { 2 - 3 } Native & $56.0( \pm 7.29) \mathrm{a}$ & $12.2( \pm 3.16) \mathrm{b}$ & $37.7( \pm 3.9) \mathrm{c}$ & $\mathrm{P}=0.05$ \\
Introduced & $36.5( \pm 9.31) \mathrm{a}$ & $42.1( \pm 5.16) \mathrm{a}$ & $42.5( \pm 3.32) \mathrm{a}$ & $\mathrm{ns}$ \\
Woody & $9.83( \pm 3.35) \mathrm{a}$ & $0.7( \pm 0.45) \mathrm{b}$ & $13.9( \pm 2.99) \mathrm{a}$ & $\mathrm{P}=0.05$ \\
Herbs & $6.8( \pm 1.17) \mathrm{a}$ & $29.64( \pm 3.67) \mathrm{b}$ & $37.12( \pm 3.21) \mathrm{b}$ & $\mathrm{P}=0.05$ \\
Grass & $73.6( \pm 5.02) \mathrm{a}$ & $33.3( \pm 5.83) \mathrm{b}$ & $32.1( \pm 4.31) \mathrm{b}$ & $\mathrm{P}=0.001$ \\
\hline No. species & & & & \\
Native & $2.9( \pm 0.39) \mathrm{a}$ & $2.4( \pm 0.46) \mathrm{a}$ & $7.2( \pm 0.82) \mathrm{b}$ & $\mathrm{P}=0.05$ \\
Introduced & $3.5( \pm 0.23) \mathrm{a}$ & $3.3( \pm 0.16) \mathrm{a}, \mathrm{b}$ & $2.8( \pm 0.43) \mathrm{b}$ & $\mathrm{P}=0.05^{1}$ \\
Woody & $0.73( \pm 0.18) \mathrm{a}$ & $0.35( \pm 0.19) \mathrm{b}$ & $1.8( \pm 0.23) \mathrm{c}$ & $\mathrm{P}=0.05^{1}$ \\
Herbs & $2.26( \pm 0.31) \mathrm{a}$ & $3.07( \pm 0.43) \mathrm{a}, \mathrm{b}$ & $3.8( \pm 0.46) \mathrm{b}$ & $\mathrm{P}=0.05$ \\
Grass & $3.4( \pm 0.21) \mathrm{a}$ & $2.71( \pm 0.39) \mathrm{a}$ & $4.1( \pm 0.19) \mathrm{a}$ & $\mathrm{P}=0.05$ \\
\hline
\end{tabular}

${ }^{1}$ Wilcoxon test was used.

${ }^{2}$ Values are means for 15 plots at two sites (Craigieburn and Mt. Barker).

${ }^{3}$ Values are means for 14 plots at two sites (Craigieburn and Tarndale).

${ }^{4}$ Values are means for 25 plots at all three sites (Craigieburn, Tarndale and Mt. Barker).

\section{Vegetation status after machine mulching}

One year after mulching at Flock Hill, vegetation cover was greatly reduced on the mulched site (Table 2). This was due to the huge reduction in cover of woody species, which included wilding pine, other introduced species and natives. Density of woody species was reduced by $48 \%$, from $25,000 \mathrm{stems} /$ ha to $13,000 \mathrm{stems} / \mathrm{ha}$. However, the reduction in wilding conifers was only $28 \%$ (from 16,600 stems/ha to $12,000 \mathrm{stems} / \mathrm{ha}$ ), indicating that mulching failed to control wildings efficiently.

Mulching had no significant effect on grass and herb cover, although there was a slight increase in the cover of the herb Rumex acetosella in the mulched area (data not shown).

TABLE 2: Plant cover (\%) in mulched and unmulched (control) sites at Flock Hill, 1 year after mulching. Mean \pm standard errors are shown.

\begin{tabular}{lccc}
\hline Cover $(\%)$ & Control (unmulched) & Mulched & Significance level \\
\hline Total & $80( \pm 6.33)$ & $49( \pm 5.32)$ & $\mathrm{P}=0.01^{1}$ \\
Grasses & $21( \pm 2.7)$ & $17.2( \pm 2.9)$ & $\mathrm{ns}^{1}$ \\
Herbs & $25( \pm 5.16)$ & $27.4( \pm 4)$ & $\mathrm{ns}^{1}$ \\
Woody species & $30( \pm 8.39)$ & $2.5( \pm 1.01)$ & $\mathrm{P}=0.01^{1}$ \\
\hline
\end{tabular}

${ }^{1}$ Wilcoxon test was used. 


\section{Vegetation development after stem-poisoning and harvesting}

Where closed canopy stands of mature (wilding) radiata pine were stem-poisoned 9 years previously in the Marlborough Sounds, an average of 15 plant species per plot was recorded, all of which were native (Table 3). Total canopy cover of native species was high $(100 \%)$, with the most common species being mahoe (Melicytus ramiflorus) and glossy karamu (Coprosma lucida). The tallest species were karamu (Coprosma robusta) and kanuka (Kunzea ericoides) at $4 \mathrm{~m}$ and $6 \mathrm{~m}$ respectively.

Vegetation cover was very different where radiata pine had been felled and harvested 5 years previously. Only nine species were recorded per plot, of which only three were native woody species (Table 3 ). By far the dominant cover was radiata pine regeneration (55\%), followed by gorse (Ulex europaeus) and cutty grass (Gahnia lacera) at $30 \%$ and $10 \%$ respectively. The tallest plants were radiata pine $(\sim 3 \mathrm{~m})$, followed by gorse $(\sim 2 \mathrm{~m})$ and bracken (Pteridium esculentum $1.5 \mathrm{~m}$ ).

The number of saplings (over $1.4 \mathrm{~m}$ tall) differed between the harvested and stempoisoned sites and the species composition was totally different. All plants were native under the poisoned trees, whereas they were virtually all radiata pine $(96 \%)$ on the harvested site.

TABLE 3: The number of plant species and stem density (number of stems per plot) of radiata pine and native species measured in stem-poisoned and harvested sites in the Marlborough Sounds. Values are the mean for three $25 \mathrm{~m}^{2}$ plots.

\begin{tabular}{lcc}
\hline & Harvested & Stem-poisoned \\
\hline All species & 9.3 & 15.3 \\
Native woody species & 3.6 & 11 \\
Native ferns & 1 & 2 \\
Native grasses & 1 & 2.3 \\
Introduced species & 3.6 & 0 \\
Radiata pine stems $(>1.4 \mathrm{~m}$ tall $)$ & $68( \pm 20.13)$ & 0 \\
Native species stems $(>1.4 \mathrm{~m}$ tall $)$ & $1.6( \pm 0.6)$ & $46.3( \pm 19.01)$ \\
\hline
\end{tabular}

\section{DISCUSSION}

Introduced conifers and wildings can grow sufficiently vigorously to completely suppress any native vegetation that may be growing on the same site. Therefore, careful management is necessary if wildings are to be used as a nurse-crop. Suppression can happen most quickly in dry environments, where the existing vegetation is often of low stature - such as in much of the eastern high country of New Zealand. The monitoring of succession from a short tussock grassland into a wilding contorta pine stand over a period of 30 years in the Craigieburn Range demonstrates this suppression well (Ledgard $\&$ Paul 2008). At other sites, such as in the Marlborough Sounds, dense stands of wilding conifers (usually radiata pine at 300-400+ stems (ha) have completely suppressed all other vegetation within 30 years of invading abandoned farmland.

There are instances where conifers can serve as good nurse crops - often by default. This is usually where the environmental conditions, particularly moisture availability, are favourable for plant growth (Brockerhoff et al. 2003). However, where moisture is limiting, it is difficult to grow a replacement understory crop beneath vigorous trees such as introduced conifers (T.S.H. Paul \& N.J. Ledgard, unpubl. data), unless silvicultural management (thinning, pruning or removal) is practised. For example, as indicated by the felled and leave situation at Mt. Barker and Craigieburn, favourable conditions for a short period can be created for new plant growth. 
With a dead 'nurse' cover, such as felled or standing dead trees, the competition for moisture, nutrients and light is not only removed or reduced, but conditions are enhanced by making these available for succeeding plants. The present studies have shown that in such circumstances, favourable growing environments can be created, especially when compared to more exposed adjacent sites. Most notable was the improved growth of grasses, both native and introduced, inside felled wilding stands compared to non-felled sites. Although this vigorous growth may decline with time and can reduce species richness by suppressing the growth and survival of lower stature species, this short term enhanced growth situation could be used to improve the development and growth for longer-lasting woody species of taller stature that are already on site or planted. This needs further investigation with possible planting trials or real time series, as some decline in cover and number of woody species was found in the present research. However, at sites not covered in this paper, woody species that were large enough to survive their initial 'burial' under felled trees, showed more vigorous growth than the same species in open conditions alongside (T.S.H. Paul \& N.J. Ledgard, unpubl. data). This suggests that artificially sown or planted shrubs and trees could also benefit from establishment within felled or killed stands. On the other hand, new opportunities are also created for invasive species like Hieracium pilosella, wilding pines or briar rose (Rosa rubiginosa), as observed in some areas at Craigieburn and Tarndale (T.S.H. Paul, unpubl. data).

Dead standing trees appear to offer a great opportunity to enhance the natural regeneration of native species. Many native seral species are more shade tolerant than the introduced conifers (particularly the pines), and therefore can preferentially invade sites where light levels are initially limited. In the low elevation sites of the Marlborough Sounds, where there are often good adjacent seed sources, and more reliable rainfall than in the high country, the restoration of native bush cover in stands of radiata pine is readily achieved after stem poisoning, which is now a widely used practice in the area (www.soundsrestoration.org.nz). This abundance of native woody regeneration on lowland sites is in contrast to the upland treated wilding pine sites of Canterbury where the option of introducing native species to stem-poisoned sites by planting and artificial seeding has yet to be properly explored. In comparison, at harvested sites at Marlborough, where there is complete canopy removal, accompanied by significant soil disturbance, conditions are ideal for a new crop of introduced light-demanding exotics including conifers, which will quickly out-compete most native species.

The control of wilding pines by mulching can result in a great reduction of live vegetation cover at a site. This is acceptable if improved pasture is the desired new cover, particularly if the removals are followed up by oversowing of pasture seed and fertilising (McIntosh et al. 1997). An increase in vegetation vigour, accompanied by enhanced grazing pressure, means that the risk of wilding reinvasion is significantly reduced. However, the present data indicate that mulching is not always successful in removing wildings, especially if the ground surface is uneven and/or trees have green branches at ground level. Residual low green branches on mulched wildings at Flock Hill were quickly 're-erecting' themselves, and due to their physiological age will soon produce cones. At another site, where wildings were older and sufficiently dense to have no green branches at ground level, mulching was a much more successful removal technique (N.J. Ledgard, unpubl. data).

The case studies outlined above illustrate how different techniques for removing wilding conifers can promote different successions of subsequent vegetation across a range of sites at both high and low altitudes. Results indicate that there are good opportunities for manipulating wilding control towards more desirable vegetation covers - particularly involving native plants. 


\section{REFERENCES}

Brockerhoff EG, Ecroyd CE, Leckie AC, Kimberley MO 2003. Diversity and succession of vascular understory plants in exotic Pinus radiata plantation forests in New Zealand. Forest Ecology and Management 185: 307-326

Langer ER, Baker GCB, 1992. Mountain beech seedling establishment using introduced conifers as a nurse crop in the South Island high country, New Zealand. In: Proceedings 2nd International Workshop ASEAN - New Zealand Inter-Institutional Linkages Programme (IILP) Project 3: Forest Rehabilitation. The Philippines, November 1993.

Ledgard NJ, Henley D, Paul TSH 2008. Chemicals for killing standing radiata pine in the Marlborough Sounds by stem poisoning. Report to South Island Wilding Conifer Management Group prepared by Scion, Christchurch, New Zealand. http://www. wildingconifers.org.nz/images/stories/wilding/Articles/Arapawa Stem Poisoning report.pdf (accessed 8 June 2009). 18 p.

Ledgard NJ, Paul TSH 2008. Vegetation successions over 30 years of high country grassland invasion by Pinus contorta. New Zealand Plant Protection 61: 98-104.

Ledgard NJ, Woods D 2007. A review of wilding control operational procedures. Report to South Island Wilding Conifer Management Group prepared by Scion, Christchurch, New Zealand. http://www.wildingconifers.org.nz/images/stories/wilding/Articles/ Obj2_review_wilding_control_operational_procedures.pdf (accessed 31 May 2009). 23 p.

McIntosh PD, Allen RB, Scott N 1997. Effects of exclosure and management on biomass and soil nutrient pools in seasonally dry high country, New Zealand. Journal of Environmental Management 51 (2): 169-186.

North H, Bartie P, Ledgard NJ 2007. Wilding conifer project report, July 2007: Objective 1 (mapping/risk assessment). Report to South Island Wilding Conifer Management Group prepared by Scion, Christchurch. New Zealand. http://www.wildingconifers. org.nz/images/stories/wilding/maps/Wilding_conifer_project_report_July_2007_ OBJ_1.pdf (accessed 31 May 2009). 3 p.

Woods D 2004. The highs and lows of wilding conifer control operations: the good, the bad and the ugly! In: Hill RL, Zydenbos SM, Bezar CM ed. Managing wilding conifers in New Zealand - present and future. New Zealand Plant Protection Society, Christchurch, New Zealand [ISBN 0-478-10842-7]. Pp. 55-63. 